\title{
Green human resource management in hotels: Awareness and implementation
}

\author{
Moataz bellah Farid
}

Hotel Studies Department, Faculty of Tourism and Hotels Suez Canal University

\author{
Haitham El-Sawalhy
}

Hotel Studies Department
Faculty of Tourism and Hotels
University of Sadat City

\begin{abstract}
Because of climate change, global warming and depletion of natural non-renewal resources the business world has become in a growing need for activities that can preserve natural environment from hazardous effects, especially that customers became more aware about the importance of environmental conservation. In the management field, it is widely known that no plan can be done effectively without human resource awareness. Hence, all activities that aim at achieving environmental goals should include transforming employees into green. This research aims at shedding light on human resource managers' awareness of green HRM practices, besides, focusing on human resource management "HRM" green practices in five star hotels. A questionnaire was directed to 28 five star hotel human resource managers in Sharm-Elshiekh. The obtained data was analyzed statistically by "SPSS" 17.The research revealed that although hotels human resource managers are aware of green HRM they are not fully deploying green HRM practices at their departments. The research recommends involving green practices into human resource management policies in order to transform hotels employees to green.
\end{abstract}

Keywords: green HRM, greening, human resource green awareness, HRM practices

\section{Introduction}

The term "green" in management refers to environmental or eco-activities. Green activities are defined as the activities that guide an organization to reduce its negative environmental impacts and preserve natural resources (Ramnus, 2002). Green organizations have several advantages such as: Reducing costs by reducing wastes, recycling materials, enhancing the property image, attracting and retaining customers who are interested in environment preservation (Haden et al., 2009). On the other hand, the main role of workforce is to achieve the organization objectives by developing and implementing business strategies. Therefore, organization should ensure that it has the talented and skilled people it needs to achieve its green policies (Phillips, 2007). Green HRM is defined as the use of HRM practices to encourage environmentalism and promote sustainable use of organization resources (Mampra, 2013).

\section{Literature Review}

Green plans effective achievement depends on whether organizations employees are green or not (Gerhart et al, 2000). The green employee, being a manager or a non-manager but should be aware of the main four green roles. First: "environmental preservationist" for keeping the natural resources in their original form, second "environmental conservationist" for carefully using natural resources to let them last as long as possible, third "Non-polluter" i.e., minimizing environmental pollution by stopping contaminating the natural resources that are negatively affected by business activities, fourth, generator of natural green areas, parks and trees to affect positively the environment (Huselid and Becker, 2000).

Green HRM refers to all practices of human resource management that aim at making organization employees green to achieve organization's environmental goals and contribute to environmental sustainability (Renwick, 2008). Later Jabbour (2011) defined green HRM as "the level of greening of human resource management practices". The integration of corporate environmental management into human resource management is termed "green HRM". According to Opatha and Arulrajah, (2014) Human resource planning, recruitment and selection, training and development, performance appraisal, rewards management and human relations which are HRM main practices are considered as tools for aligning employees with organization's environmental policies. 


\section{A. Green Human resource planning, recruitment and selection}

Green human resource planning is defined as "The systematic and continuing process of analyzing organization's green human resource needs under changing conditions and developing green personnel policies appropriate to the longer-term effectiveness of the organization"(Daily and Huang, 2001). Again, It aims to ensure that the organization obtains and retains the quantity and quality of people it needs to achieve its environmental goals (Jackson et al., 2011). Based on Green human resource planning the organization can be able to develop resourcing strategies through the analysis of business strategies by forecasting numbers and types of employees needed to implement the organization's environmental management activities and deciding policies to meet the anticipated demand for environmental activities (Opatha, 2013).

In order to facilitate green HRM planning practices, employees' job analysis should be written from the view of green perspective. That means that both job description and job specification should contain employees' environmental data. So, job description should contain employee's environmental tasks and responsibilities. Moreover, job specification should contain the required knowledge, skills, and abilities needed to achieve these tasks and responsibilities (Renwick, 2008).

Effective environmental green employees recruitment and selection is based on two options, whether to focus on green recruitments of new candidates, or to provide existing employees with required environmental background related to awareness, training and development (Ramnus, 2002). Green recruitment and selection means merging corporate environmental policies with the organization's recruitment and selection policies (Phillips, 2007). On the other hand, attracting green employees is a mutual need between the organization and job candidates, as there is a growing number of people concerned with implementing environmental roles in their jobs (Clarke, 2006).

According to Opatha (2013) green recruitment should be based on transparent organization's environmental performance when advertising recruitment messages, i.e. expressing environmental values when advertising new jobs, showing priority to recruit candidates who have interest to participate in environmental roles, including green recruitment criteria in the recruitment messages. Moreover, when selecting candidates by interviews or any other evaluation tools, environmental-related questions are very important to evaluate candidates' environmental concern and awareness. In addition, candidates who have been engaged in green activities under their private life should have selection priority (Revill, 2000).

\section{B. Green training and development}

The main objectives of green human resource training and development are to provide environmental training courses and to create environmental awareness among all organizations' employees. Hence, Designing environmental training programs begins with identifying employees environmental training needs analysis criteria in order to provide needed environmental knowledge, skills and attitudes to employees (Ramnus, 2002). Jackson et al. (2011) developed other green training and development practices such as training employees to workspace from green aspects, applying job rotation to train green managers of the future, designing training programs to make the employees greener.

The first step of human resource Training and development is the induction. In this phase, companies should ensure that new recruits understand their environmental responsibilities, adopt the organizations environmental practices and are encouraged to be engaged in the organization's green behavior (Revill, 2000).

\section{Green performance appraisal}

Employees' green performance appraisal is one of the quality indicators of green HRM in the organization. Green performance management is the process through which the organization evaluates green work over a set period, provides green feedback, and resets individuals green goals(Armstrong, 2014).Hence, In order to effectively evaluate employees green performance appraisal, organizations should: set green goals for every employee, develop green criteria integrated into the performance appraisal process, assure that every 
employee had made a green performance feedback interview as a separate part of performance feedback interview (Opatha, 2013).

\section{Green Reward Management}

Green reward management deals with policies and processes required to ensure that employees green performance are recognized by both financial (e.g. bonuses, incentives, cash) and/or non-financial means (e.g. awards, prizes) to motivate their environmental responsibilities (Renwick, 2008). Some companies developed environmental criteria included into salary reviews; others created recognized rewards for environmental performance excellence (Bhushan and Mackenzie, 1994).

\section{E. Green employee relations}

Green employee relations include employees' involvement into environmental social responsibility; i.e. participating in green suggestion schemes, developing training courses for the union representatives in environmental management, providing consultations in solving environmental issues, cooperating with stakeholders in all environmental issues(Renwick et al, 2013).

\section{Research objectives}

The research aims to clarify human resource managers' awareness towards Green HRM in hotels and to investigate to what extent the green HRM practices are implemented in hotel industry.

\section{Hypotheses}

Based on the previous objectives, the research hypothesizes the following Hypotheses (Hs)

H1: Human resource managers in hotels are sufficiently aware of green HRM;

H2: Human resource departments in hotels are fully implementing green HRM practices;

H3: There is a statistical relationship between the awareness of hotels management regarding green HRM and the implementation of green HRM practices;

H4: There are statistical differences among hotels according to management pattern in the implementation of green HRM practices.

\section{Methodology}

A questionnaire was directed to 28 five star hotel human resource managers in Sharm-Elshiekh. The questionnaire began with (6) questions for respondents personal data. Then it was divided into two sections: Section (1) consisted of (8) questions to measure hotels human resource managers awareness about Green HRM. Section (2) was based on various researches on Green HRM in recent years (Renwick, 2008; Jabbour et al., 2010; Jabbour, 2011; Opatha, 2013; Opatha and Arulrajah, 2014). It consisted of the main five practices of green human resource management: A) Planning, Recruitment and selection, B) Training and development, C) Performance evaluation, D) Rewards management, and E) Employee relations. Each of practices consisted of (5) questions related to green activities. The questionnaires used a five point likert-type scale ranging from " $1=$ strongly disagree" to " $5=$ strongly agree" to score the responses. The obtained data was analyzed statistically by Statistical package for social sciences program "SPSS" volume 17 to obtain Descriptive analysis and to calculate reliability and validity analysis, Spearman correlation analysis and Mann-Whitney U Test.

\section{Results and Discussion}

\section{Reliability and validity analysis}

Cronbach's Alpha was used to measure the internal consistency of the study instrument. In addition, validity was used to validate the constructs of the questionnaire. Both reliability and validity are assessed in order to ensure the validity of findings of the present study. The coefficient alpha of awareness and perception towards green HRM, the implementation of green HRM practices and the overall of reliability and validity coefficient are presented in table 1. 
Table 1: Coefficient of reliability and validity of the questionnaire

\begin{tabular}{|c|c|c|c|c|}
\hline No. & Constructs & $\begin{array}{c}\text { No. of } \\
\text { items }\end{array}$ & $\begin{array}{c}\text { Cronbach's } \\
\text { Alpha }\end{array}$ & Validity \\
\hline $\mathbf{1}$ & Awareness of green HRM & $\mathbf{8}$ & .958 & .97 \\
\hline $\mathbf{2}$ & $\begin{array}{c}\text { Implementation of green } \\
\text { HRM practices }\end{array}$ & $\mathbf{2 5}$ & .977 & .98 \\
\hline \multicolumn{1}{|c|}{ Overall Total Scale } & $\mathbf{3 3}$ & $\mathbf{. 9 7 7}$ & $\mathbf{. 9 8}$ \\
\hline
\end{tabular}

The previous table illustrated that the coefficient of Cronbach's Alpha for two constructs of the questionnaire had high alpha coefficient scores (97\%). Moreover, the overall validity coefficient of two constructs of the study was $98 \%$. DeVellis (2012) indicates that alpha coefficient should be equal or above .70. Therefore, this result assures that the instrument of the study is reliable. In other words, the items used in the questionnaire are measuring what it supposed to measure.

\section{Descriptive Statistics}

The demographic profile of the respondents, awareness/ perception of management towards green HRM and the implementation of green HRM practices organized into categories and tabulated by using frequencies, percentage, mean scores and standard deviation.

\subsection{Demographic profile of the respondents}

The respondents' demographic data are shown in table (2). Out of 28 respondents, 26 of them (92.9\%) were males while the remaining two respondents $(7.1 \%)$ were females. In terms of age, it is noted that the majority of the respondents were of 35 and 45 years old (53.6\%), followed by those of below 35 years old (28.6\%). The smallest group was those above 45 years old (17.9\%). According to the educational level, the majority of the study respondents held college degree $(71.4 \%)$ while $28.6 \%$ of them held postgraduate degree. Based on the collected data, $64.3 \%$ of the respondents work as human resource manager while $35.7 \%$ were assistant human resource manager. As illustrated in Table 2, the majority of the respondents had work experience of less than 10 year $(64.3 \%)$, while 6 respondent $(21.4 \%)$ had 10 to 15 years and only 4 respondents $(14.3 \%)$ have had work experience of more than 15 years. According to the type of hotel's management, $50 \%$ of hotels were chain management while the other $50 \%$ of hotels were owner-management hotels. 
Table 2: The respondents' demographic profile

\begin{tabular}{|c|c|c|c|}
\hline Demographics & $\begin{array}{l}\text { Characteristics and } \\
\text { Classification }\end{array}$ & $\begin{array}{l}\text { Frequency } \\
\text { (N) }\end{array}$ & $\begin{array}{c}\text { Percentage } \\
(\%)\end{array}$ \\
\hline Gender & $\begin{array}{l}\text { Male } \\
\text { Female }\end{array}$ & $\begin{array}{c}26 \\
2\end{array}$ & $\begin{array}{c}92.9 \\
7.1\end{array}$ \\
\hline Age & $\begin{array}{l}\text { Below } 35 \text { years old } \\
35-45 \text { years old } \\
\text { Above } 45 \text { years old }\end{array}$ & $\begin{array}{c}8 \\
15 \\
5\end{array}$ & $\begin{array}{l}28.6 \\
53.6 \\
17.9\end{array}$ \\
\hline $\begin{array}{l}\text { Educational } \\
\text { background }\end{array}$ & $\begin{array}{l}\text { College } \\
\text { Postgraduate }\end{array}$ & $\begin{array}{c}20 \\
8\end{array}$ & $\begin{array}{l}71.4 \\
28.6\end{array}$ \\
\hline Position & $\begin{array}{l}\text { Human resource manage } \\
\text { Ass. Human resource manager }\end{array}$ & $\begin{array}{l}18 \\
10\end{array}$ & $\begin{array}{l}64.3 \\
35.7\end{array}$ \\
\hline $\begin{array}{c}\text { Work } \\
\text { Experience }\end{array}$ & $\begin{array}{l}\text { Less than } 10 \text { years } \\
10 \text { - } 15 \text { years } \\
\text { More than } 15 \text { years }\end{array}$ & $\begin{array}{c}18 \\
6 \\
4\end{array}$ & $\begin{array}{l}64.3 \\
21.4 \\
14.3\end{array}$ \\
\hline $\begin{array}{c}\text { Type of } \\
\text { management }\end{array}$ & $\begin{array}{l}\text { Owner-management } \\
\text { Chain }\end{array}$ & $\begin{array}{l}14 \\
14\end{array}$ & $\begin{array}{l}50 \\
50\end{array}$ \\
\hline
\end{tabular}

\subsection{The awareness/ Perception of hotel management towards green HRM}

The mean scores and standard deviation were calculated for each item that had been assessed through the questionnaire. A five point likert-type scale (ranging from one that means strongly disagree to five that means strongly agree) was used to measure the awareness and perception towards green HRM (Table 3 ). 
Table 3: Awareness/ Perception of hotels management towards green HRM

\begin{tabular}{|c|l|c|c|}
\hline No. & \multicolumn{1}{|c|}{ Statement } & Mean & $\begin{array}{c}\text { Std. } \\
\text { deviation }\end{array}$ \\
\hline $\mathbf{1}$ & $\begin{array}{l}\text { HR managers are sufficiently aware of the } \\
\text { concept "Green HRM". }\end{array}$ & 4.18 & 1.124 \\
\hline $\mathbf{2}$ & $\begin{array}{l}\text { The organization implements green HRM } \\
\text { initiatives. }\end{array}$ & 3.39 & 1.227 \\
\hline $\mathbf{3}$ & $\begin{array}{l}\text { HR department motivates employees to follow } \\
\text { green initiatives. }\end{array}$ & 3.46 & 1.071 \\
\hline $\mathbf{4}$ & $\begin{array}{l}\text { The organization has formal procedures and } \\
\text { policies for implementing green HRM practices. }\end{array}$ & 3.46 & 1.290 \\
\hline $\mathbf{5}$ & $\begin{array}{l}\text { Green HRM practices are very important to } \\
\text { hospitality organizations. }\end{array}$ & 4.29 & .897 \\
\hline $\mathbf{6}$ & $\begin{array}{l}\text { Green HRM contributes to successful } \\
\text { environmental management. }\end{array}$ & 4.43 & .790 \\
\hline $\mathbf{7}$ & $\begin{array}{l}\text { Green HRM practices are important to the } \\
\text { competitiveness of the organization. }\end{array}$ & $\mathbf{3 . 9 7}$ & $\mathbf{. 9 2 2}$ \\
\hline $\mathbf{8}$ & $\begin{array}{l}\text { Green HRM practices are important to achieve } \\
\text { long-term profitability. }\end{array}$ & 4.39 & .956 \\
\hline & \begin{tabular}{ll} 
Overall Mean \\
\hline
\end{tabular}
\end{tabular}

Note: Scale range is from " $1=$ strongly disagree" to " $5=$ strongly agree"

Table 3 demonstrates that the overall mean score for the statements of the awareness was 3.97. According to the findings, human resource managers in hotels were aware enough and familiar with the green HRM concept (4.18), the hotels implement green HRM initiatives (3.39), the HR departments motivate employees to follow green initiatives (3.46). They also assured that there are formal procedures and policies for implementing HRM practices (3.46). Moreover, the human resource managers in the hotels of the study agreed that green HRM practices are very important to hospitality organizations (4.29), green HRM contributes to successful environmental management (4.43), green HRM practices are important to the competitiveness of the organization (4.36) and green HRM practices are important to achieve long-term profitability (4.39). According to Garavan et al. (2010) green human resource requirements need to be cleared and identified to all employees specially managers and decision makers in order to achieve organizational environmental goals. In other words, all department managers must have sufficient amount of knowledge in greening without which, it is impossible to deploy green policies in their departments. The present results indicate that hotels management are aware of green HRM. Hence, the first hypothesis (H1) that says, "human resource managers in hotels are sufficiently aware of green HRM" is accepted.

\subsection{The implementation of green HRM practices}

The mean scores and standard deviation computed for each function or practice of green HRM practices that had been assessed through the questionnaire. A five point likert-type scale was used to measure the implementation of green HRM practices in hotels.

The mean scores of the implementation of green HRM practices are listed in table 4 . 
Table 4: The implementation of green HRM practices in hotels

\begin{tabular}{|c|l|c|c|}
\hline No. & \multicolumn{1}{|c|}{ Statement } & Mean & $\begin{array}{c}\text { Std. } \\
\text { deviation }\end{array}$ \\
\hline $\mathbf{1}$ & Recruitment and selection & 2.38 & 1.172 \\
\hline $\mathbf{2}$ & Training and development & 3.39 & 1.097 \\
\hline $\mathbf{3}$ & Performance appraisal & 2.38 & 1.046 \\
\hline $\mathbf{4}$ & Rewards management & 2.40 & 1.069 \\
\hline $\mathbf{5}$ & Work relations. & 2.79 & 1.294 \\
\hline & Overall Mean & $\mathbf{2 . 6 7}$ & $\mathbf{1 . 0 0}$ \\
\hline
\end{tabular}

Note: Scale range is from " $1=$ strongly disagree" to " $5=$ strongly agree"

The overall mean score for the implementation of green HRM practices was 2.67. In other words, hotels' managements are not sufficiently implementing green policies and procedures in HRM practices such as recruitment and selection (2.38), performance appraisal (2.38), Rewards management (2.40) and work relations (2.79). While to some extent they implement green policies and procedures in training and development (3.39). These results imply a clear shortage at green HRM practices implementation. According to Opatha \& Arulrajah (2014) It is indispensable to HRM functions to be adapted or modified to be green, In order to make sure that the organization gets right green employee,. So, the second hypothesis (H2) that says, "Human resource departments in hotels fully implementing green HRM practices" is rejected. Therefore, human resource management in hotels should be more interested in implementing green HRM in their Functions and practices.

\section{Correlation analysis}

The Spearman correlation was used to calculate the correlation between the awareness of green HRM and the implementation. Table (5) indicates that Spearman correlation (0.622) was obtained between the HR managers' awareness of green HRM and the implementation of green HRM practices. This result is highly significant at (0.01) level. In addition, the correlation was relatively high and positive.

Table 5: The relationship between awareness and the implementation of green HRM practices

\begin{tabular}{|c|c|c|c|c|}
\hline \multirow{7}{*}{ Spearman } & Variables & & $\begin{array}{l}\text { Awareness of } \\
\text { green HRM }\end{array}$ & $\begin{array}{l}\text { Implementation of } \\
\text { green HRM } \\
\text { practices }\end{array}$ \\
\hline & & Correlation & 1.000 & $.622 * *$ \\
\hline & & Sig. (2-tailed) & & .000 \\
\hline & $\begin{array}{l}\text { Awareness of green } \\
\text { HRM }\end{array}$ & $\mathrm{N}$ & 28 & 28 \\
\hline & & Correlation & $.622 * *$ & 1.000 \\
\hline & Implementation of green & Sig. (2-tailed) & .000 & \\
\hline & HRM practices & $\mathrm{N}$ & 28 & 28 \\
\hline
\end{tabular}


** Correlation is significant at the 0.01 level (2-tailed).

According to the previous findings, the third hypothesis (H3) that says, "there is a statistical relationship between the awareness of hotels management regard to green HRM and the implementation of green HRM practices" is accepted.

4. Differences among hotels according to the management pattern

The study used Mann-Whitney U Test to clarify the differences between hotels according to their management type regarding the awareness of green HRM and its implementation. Mann-Whitney U values and mean rank scores are listed in table 6.

Table 6: Differences between hotels according to management type

\begin{tabular}{|c|c|c|c|c|c|}
\hline Variables & $\begin{array}{c}\text { Type of } \\
\text { Management }\end{array}$ & $\mathbf{N}$ & $\begin{array}{c}\text { Mann- } \\
\text { Whitney U }\end{array}$ & Mean Rank & Sig. \\
\hline \multirow[t]{2}{*}{ Awareness of green HRM } & $\begin{array}{l}\text { Owner- } \\
\text { management } \\
\text { Chain }\end{array}$ & $\begin{array}{l}14 \\
14\end{array}$ & $\mathbf{5 7 . 5 0}$ & $\begin{array}{l}11.61 \\
17.39\end{array}$ & \multirow{2}{*}{.061} \\
\hline & Total & 28 & & & \\
\hline \multirow[t]{2}{*}{$\begin{array}{c}\text { Implementation of green } \\
\text { HRM practices }\end{array}$} & $\begin{array}{l}\text { Owner- } \\
\text { management } \\
\text { Chain }\end{array}$ & $\begin{array}{l}14 \\
14\end{array}$ & 23.50 & $\begin{array}{c}9.18 \\
19.82\end{array}$ & \multirow{2}{*}{.000} \\
\hline & Total & 28 & & & \\
\hline
\end{tabular}

Table 6 shows no significant differences among hotels regarding the management pattern, The P. value being $(0.061)$, is more than .05 . This means that both chain and owner-management hotel managers have a positive awareness and perception towards green HRM and they were sufficiently familiar with the "green HRM" concept.

On the other hand, there were statistically significant differences among hotels in the implementation of green HRM practices, The P. value was (0.00), and this value is less than .05 indicating that chain hotels managements implement green HRM practices better than owner-managed. Hence, the fourth hypothesis (H4) saying, "there are statistical differences among hotels according to management pattern in the implementation of green HRM practices" is accepted.

\section{Conclusion and Recommendation}

Although hotels human resource managers have positive awareness of green HRM they are not fully integrating green HRM practices into their departments. In order to deploy green HRM integrated practices into hotels, the research recommends involving these practices into hotels HRM policies; this involvement must cover all HRM following functions: human resource planning, recruitment and selection, training and development, performance appraisal, rewards management and work relations to assure transforming employees to green.

\section{References}

Armstrong M., (2014) Armstrong's handbook of Human Resource Management Practice, $20^{\text {th }}$ ed., British Library, UK, PP 333-391

Bhushan, A.K. and Mackenzie, J.C. (1994), Environmental leadership plus total quality management equals continuous improvement, Environmental TQM, 2nd ed., McGraw-Hill, New York, pp. 72-93.

Clarke, E. (2006), Power Brokers, People Management, $18^{\text {th }}$ May, pp. 40-42.

Daily, B., and Huang, S. (2001). Achieving sustainability through attention to human resource factors in environmental management. International Journal of Operations and Production Management, vol.21, pp. $1539-1552$.

DeVellis, R. F. (2012). Scale development: Theory and applications. Los Angeles: Sage. pp. 109-110. 
Garavan, T. N.; Heraty, N., Rock, A.; and Dalton, E. (2010). Conceptualizing the behavioral barriers to CSR and CS in organizations: A Typology of HRD Interventions. Advances in developing human resource, 12(5), PP. 587-613

Gerhart, B. Wright; P.M. McMahan; G.C. and Snell; S.A. (2000), Measurement Error in Research on Human Resource and Firm Performance: How Much Error is There and How Does it Influence Effect Size Estimates, Personnel Psychology, Vol. 53, No. 4. pp. 803-834.

Haden, S. S. P.; Oyler, J. D.; and Humphrey, J. H. (2009). Historical, practical, and theoretical perspectives on green management. An Exploratory Analysis Management Decision, 47, 1041-1055.

Huselid, M. A. and Becker, B.E. (2000), Comment on „Measurement Errore in Research on Human Resource and Firm Performance: How Much Error is There and How Does it Influence Effect Size Estimates?. Personnel Psychology, Vol. 53, pp. 835-854.

Jackson, S.E.; Renwick, D. W. S.; Jabbour C.J. C. and Camen, M.M.(2011), State-of-the-Art and Future Directions for Green Human Resource Management: Introduction to the Special Issue, German Journal of Research in Human Resource Management, Vol. 25, No. 2, pp. 99-116.

Jabbour, C.J.C. (2011), How green are HRM practices, organizational culture, learning and teamwork? A Brazilian study, Industrial and Commercial Training, Vol. 43, No. 2, pp. 98 -105.

Mampra, M. (2013). Green HRM: Does it help to build a competitive service sector? A study. In Proceedings of tenth AIMS International Conference on Management, pp. 1273-1281

Opatha, H. H. D. N. P. (2013), Green Human Resource Management: A Simplified Introduction, HR Dialogue, Department of HRM, Faculty of Management Studies and Commerce, University of Sri Jayewardenepura, pp. 22-41.

Opatha, H. H. D. N. P. and Arulrajah, A. (2014), Green Human Resource Management: A Simplified General Reflections, International Business Research, Vol. 7, No. 8, pp. 101-112.

Phillips, L. (2007), Go Green to Gain the Edge over Rivals, People Management, 23rd August, p.9.

Ramnus, C. A. (2002). Encouraging innovative environmental actions: What companies and managers must do. Journal of World Business, 37, 151-164.

Renwick, D. (2008). Green HRM: A review, process model, and research agenda (Discussion Paper Series). The University of Sheffield.

Renwick, D. W.S.; Redman, T. and Maguire, S. (2013). Green Human Resource Management: A review and research agenda. International Journal of Management Reviews,15(1), 1-14.

Revill, C. (2000), The „Greening of Personnel/Human Resource Management an Assessment, International Journal of Applied HRM, Vol.1, No. 3, pp. 1-30. 
الملخص العربي الدو افع التي أدت بالمؤسسات إلى نز ايد الاهنمام بالنظم البيئية الخضر اء، ومنها تز ايد حجم الملوثات وندرة الموارد الطبيعية

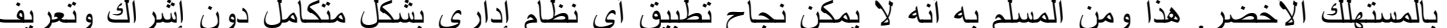

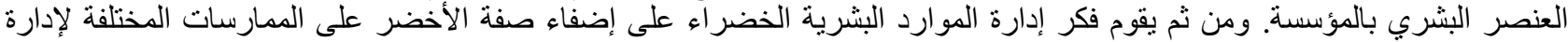

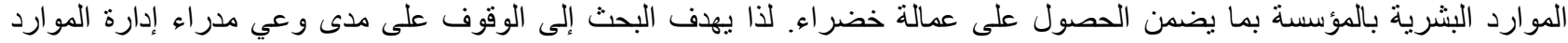

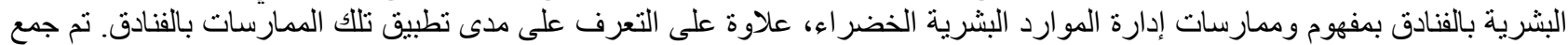

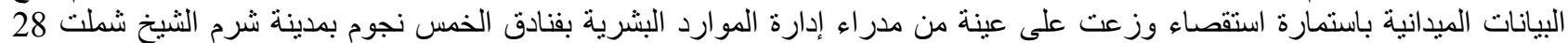

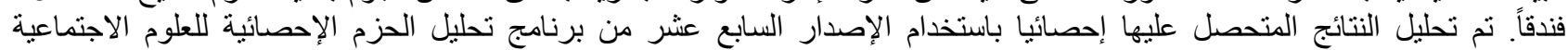

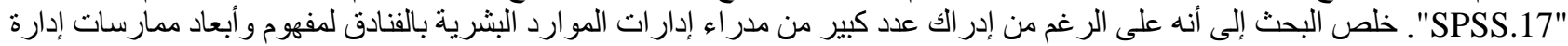

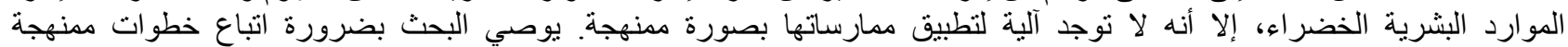

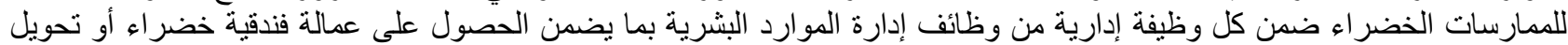
العمالة الحالية إلى عمالة خضر الخراء. 